\title{
DIALECTICS OF PESANTREN AND SOCIAL COMMUNITY IN CULTURAL VALUE TRANSFORMATION
}

\author{
Subakri \\ State Islamic Institute of Jember \\ Email: cakbakri@gmail.com \\ Rosdee Ibrahim Mangkachi \\ Pattana Wiyata School Thailand \\ Email:mangkachi@gmail.com
}

\begin{abstract}
Pesantren tends to have an adaptive response towards social changes in community life. This research employed a qualitative approach by using a case study to discern the adaptive strategy of an Islamic boarding school. Then, the data were collected through observations, interviews, and documentaries. Next, they were analyzed using the Miles and Huberman model, namely data collection, condensation, data display, and conclusions drawing simultaneously. Finally, the validity of the data was gained through triangulation. The study results showed that pesantren has actively adapted themselves towards these social demands. Furthermore, it shows that 1) the dialectics of pesantren and social community in transforming cultural values through formal education was done by establishing several formal educations; 2 ) the dialectics of pesantren and social community in transforming cultural values through non-formal education was done by establishing several non-formal religious-based institutions through pesantren activities.
\end{abstract}

Abstrak: Pesantren dalam kehidupan masyarak a t memiliki sikap adaptif terhadap perubahan. Penelitian ini menggunakan pendekatan kualitatif adapun jenis penelitian studi kasus. Penggalian sumber data menggun a kan Observ a si, wawancara dan dukumenter dan data dianalisi dengan model Miles and Hubermen yaitu pengumpulan data, kondensasi data, penyajian data dan pe narikan ke s impulan yang dilakukan bersama. Kemudian keabsahan data menggunakan Triangulasi. Adapun hasil kajian penelitian yaitu pesantren Raudlatul Ulum memiliki sikap adaptif terhadap perubahan yang tergambar sebagai berikut 1.) Dialekti ka Pondok P e santren Raudlatul Ulum dan masyarakat dalam tranformasi nilai budaya melalui Pendidikan formal dengan mendirikan beberapa pendidikan formal. 2) Dialektika Pondok Pesantren Raudlatul Ulum dan masyarakat dalam tranformasi nilai budaya melalui Pendidikan non formal dengan jalan mendirikan beberapa lembaga non formal yang berbasis keagamaan yang teraktualisasikan melalui aktivitas Pondok Pesantren. 
Keywords: dialectics; pesantren; social communities; cultural values; cultural transformation.

\section{INTRODUCTION}

The recent globalization has a significant influence on global changes. Bagus Susetyo said that cultural change occurs in almost all aspects of human life, including Islamic boarding schools. ${ }^{1}$ However, Islamic boarding schools continue to maintain the values held and have always been considered a reference for some Muslim communities. It is reflected from Hiroko Horikoshi's study in West Java as cited by Ahmat Royani, who concluded that the pesantren represented by Kyai (Islamic scholar) had played the role of "the genuine entrepreneur."

In terms of social community roles, Azyumardi argues that pesantren has at least three main functions. The first, the transmission of Islamic knowledge; the second, the maintenance of Islamic Tradition; the third, the reproduction of ulama (Islamic scholars) candidates. ${ }^{3}$ In this matter, pesantren plays a crucial role in responding to the changes. A study conducted by Dhofier clearly describes the socio-political changes affecting the social community within the pesantren and its surroundings. ${ }^{4}$ Furthermore, Hoffman's Moral Socialization Theory, as explained by Rasid Yunus, said about the process of transforming cultural values. Based on this theory, it emphasizes the values and norms that previously existed in the culture of social community, which is transformed or conveyed to the social community. ${ }^{5}$

Raudlatul Ulum Curahtakir Tempurejo Islamic Boarding School and other pesantren did not conserve within a spiritual life. Still, it is in the midst of social community, whose presence is something new and faces people who have an identity and value system and a cultural system. The dialectical process of the Raudlatul Ulum Islamic Boarding School with the community continues to occur and maintain the community's cultural values. Thus, the Raudlatul Ulum Curahtakir Tempurejo Islamic Boarding School in Jember has always been

1 Bagus Susetyo, 'Identifikasi Dekulturasi Sebagai Teori Perubahan Kebudayaan Dalam Musik Indonesia: Kajian Proses Perubahan Rebana Menjadi Kasidah Modern Di Kota Semarang', Harmonia: Journal of Arts Research and Education 10, no. 1 (2010)

2 Ahmad Royani, 'Eksistensi Pendidikan Pesantren Dalam Arus Perubahan', Cendekia: Jurnal Kependidikan Dan Kemasyarakatan 16, no. 2 (22 November 2018): 375, https://doi. org/10.21154/cendekia.v16i2.1242.

3 Azyumardi Azra, Esei-Esei Intelektual Muslim Dan Pendidikan Islam, Cet. 1 (Ciputat: Logos Wacana Ilmu, 1999), 89.

4 Zamakhsyari Dhofier Lombard, Tradisi Pesantren, Studi Tentang Pandangan Hidup Kyai. Archipel., 1984.

5 Rasid Yunus, 'Transformasi Nilai-Nilai Budaya Lokal Sebagai Upaya Pembangunan', Jurnal Penelitian Pendidikan (JPP), Universitas Pendidikan Indonesia 13, no. 1 (2013). 
central to respond to any changes in the existing cultural value order, especially the surrounding community.

The dialectic between pesantren and the Curahtakir community continues and will never be completed in the historical trajectory. However, it always experiences fluctuating conditions in its journey. Both are in a dynamic circle of social construction and constantly change due to inevitable factors such as globalization, technology, politics, economy, and social. Based on anthropological, sociological, and demographic perspectives, Curahtakir Villagers are agrarian societies. Most of them are farmers. Hence, the changes are sometimes surprising for some people. The preliminary study identified that the people of Curahtakir Village look stuttering when they experience changes in technology and culture. ${ }^{6}$ However, this is not the case for the Raudlatul Ulum Islamic boarding school. As a boarding school whose Khalaf existence cannot be separated from the influences of technology and culture, it has been filtered. The ornaments of globalization have highlighted its existence to maintain the pesantren's culture.

This study provides such an exciting result by focusing on the dialectical issues of the Raudlatul Ulum Islamic Boarding School and social community in transforming cultural values through formal and non-formal education. There have been many studies on the relationship between pesantren and social community conducted by previous researchers, such as research by Dakir and Umiarso on pesantren and social change: the optimization of social capital for the advancement of the social community. The results of this study emphasize the progress of pesantren in mobilizing social values and norms so that they can make changes in a social capital perspective. ${ }^{7}$ A study from Hendi Kariyanto examines the role of pesantren in modern social community and its role in providing continuous relationships to maintain religious values. ${ }^{8}$ A results study of Mohammad Mustari, Dedeng Yusuf Maolani emphasizes the independence of pesantren. The pesantren design themselves and build their own for both the pesantren and the village community. It is because most of the pesantren are located in rural areas. ${ }^{9}$ Some of the many studies regarding pesantren and its relationship with social community carried out by previous researchers have a

6 Observation done on November 1st 2020, n.d.

7 Dakir and Umiarso Umiarso, 'Pesantren Dan Perubahan Sosial: Optimalisasi Modal Sosial Bagi Kemajuan Masyarakat', Al-A'raf : Jurnal Pemikiran Islam Dan Filsafat 14, no. 1 (27 June 2017): 1, https://doi.org/10.22515/ajpif.v14i1.587.

8 Hendi Kariyanto, 'Peran Pondok Pesantren Dalam Masyarakat Modern', n.d., https:// ejournal.iainbengkulu.ac.id/index.php/multikultura/article/view/2495.

9 Mohammad Mustari and Dedeng Yusuf Maolani, 'Manajemen Pesantren Dalam Pembangunan Desa', TEMALI : Jurnal Pembangunan Sosial 1, no. 2 (1 October 2018): 167-92, https://doi.org/10.15575/jt.v1i2.3214. 
novelty that distinguishes it from previous research regarding pesantren and the education that runs its excesses cultural values of the social community.

In terms of theoretical studies, the main problem of this research is to examine and systematically and deeply analyze how the dialectic of the Raudlatul Ulum Curahtakir Tempurejo Jember Islamic boarding school and social community in transforming cultural values to see the validity and application of the theory of Cultural Values Transformation, with focuses on the Raudlatul Ulum Islamic boarding school and the Curahtakir community which is formulated with the question: "What is the dialectic of the Raudlatul Ulum Curahtakir Tempurejo Islamic Boarding School and social community in the transformation of cultural values?'; "How is the dialectic of the Raudlatul Ulum Curahtakir Tempurejo Islamic Boarding School and social community in the transformation of the cultural value through formal education?"; and "How is the dialectic of Raudlatul Ulum Curahtakir Tempurejo Islamic Boarding School and social community in transforming cultural values through non-formal education?"

This study aims to construct a systematic and in-depth analysis of the question related to how the dialectic of the Raudlatul Ulum Curahtakir Tempurejo Jember Islamic Boarding School and social community in transforming cultural values. The purpose of this study is to describe how the dialectic of the Raudlatul Ulum Curahtakir Tempurejo Jember Islamic Boarding School and social community in the transformation of the cultural value, especially in the aspect of educational institutions implemented both formal and non-formal education.

\section{RESEARCH METHODS}

The design of this study was a case study. This descriptive qualitative research was conducted at the Raudlatul Ulum Curahtakir Tempurejo Islamic Boarding School, Jember. It was conducted from November 1st in 2020 to January 9 th in 2021. The data were collected through observation, interviews, and documentation. The data were analyzed using Miles and Huberman's theory, including data collection, condensation, data display, and conclusions drawing. Then, the validity of the data was checked through triangulation either time, source, or method triangulation.

\section{THEORETICAL FRAMEWORK}

\section{Pesantren and Social Community}

From the historical study, Islamic boarding schools were born because of the demands of the community for religious education, which began with the learning of fiqh, hadith, tafsir, and some others. People who felt a need for this education came to perceive knowledge and eventually became widely known in the community. As expressed by M. Shodiq, the students then came from 
everywhere to become santri. ${ }^{10}$ Therefore, Pesantren, born from the community, should not leave the social community but should always answer community needs by maintaining a harmonious relationship and providing benefits to the community. From this, pesantren has always been an Islamic-based educational institution where students can appreciate differences through their social interaction (silaturahim) inside and outside the pesantren itself. ${ }^{11}$

Islamic boarding schools amid cultural shifting values of social community due to the transformation process, seen from Kuntowijoyo statement quoted by Syahmari, perceive the transformation in two things; social and cultural. ${ }^{12}$ It has a strategic role from cultural shift to become a stronghold of noble and good cultural values. But, on the other hand, the great movement of societal change due to global alteration is not necessarily in accordance with the values and culture developed and maintained so far.

This phenomenon has become a demanding contest for vigilance and resilience within the social community in maintaining the noble, authentic, and good values that are in accordance with the character and personality of the social community itself. As the Relational Dialectics Theory explains it by Mikhail Bakhtin studied by Muniruddin that life is an open monologue, and humans experience is a collision between opposing their wants and needs in relational communication. ${ }^{13}$ Within the conditions that can bring the uncertain changes, pesantren responsible for making a maximum contribution to the development of the local community, starting from increasing the level of worshiping act (religious activities) to the economic changes experienced by the community around the boarding school, especially education.

In the educational context, pesantren is an educational institution that has a long history and experience in assisting the social community and living amid a social community itself that has dynamic cultural values as stated by Mahmuddin Sudin that pesantren in the historical development of education in Indonesia is seen as the oldest institution, and has the sustainable role of national education. ${ }^{14}$ So that in the educational transformation, many pesantren follow the current

${ }^{10}$ M Shodiq, 'Pesantren Dan Perubahan Sosial', Jurnal Sosiologi 1 (2011): 12.

${ }^{11}$ Siti Rohmaturrosyidah Ratnawati,. 'Multiculural-Based Islamic Religious Education in Ahmadiyah's School: A Strategy to Strenghten the Moderation Vision of Indonesian Islamic School. Cendekia: Jurnal Kependidikan dan Kemasyarakatan, 18, no. 12020.

${ }^{12}$ Syamhari, 'Transformasi Nilai-Nilai Budaya Islam Di Sulawesi Selatan', Rihlah : Jurnal Sejarah Dan Kebudayaan 2, no. 2 (2015).

${ }^{13}$ Muniruddin, 'Komunikasi Pengembangan Masyarakat Islam Analisis Teori Dialektika Relasional', Jurnal Pemberdayaan Masyarakat 7, no. 1 (24 August 2019): 13, https://doi. org/10.37064/jpm.v7i1.5608.

${ }^{14}$ Mahmuddin Sudin, 'Pesantren, Transformasi Sosial Dan Kebangkitan Intelektualisme Islam', n.d., https://jurnal.umj.ac.id/index.php/MaA16/article/view/3816. 
national education movement known as the Kholaf pesantren, and some retain the old and more traditional models of the Salaf pesantren.

The condition of a functional Islamic boarding school educational institution makes the Islamic boarding school always provide answers to the community's needs, especially in dealing with problems of social life that are experiencing significant and rapid changes related to science and technology. Examining further the existence of pesantren, even from the colonial period, pesantren had become the archipelago's educational system. According to Nurcholish Madjid's view, pesantren contains the Islamic meaning and the authenticity of Indigenous Indonesia. ${ }^{15}$ Meanwhile, according to Muammar Ramadhan and Puji Dwi Darmoko, Islamic boarding schools, especially in the centers of the Islamic kingdom, have more or less similar educational institutions even though they use different names Meunasah in Aceh, Surau in Minangkabau, and pesantren in Java. ${ }^{16}$ Furthermore, pesantren, by displaying inclusive Islamic teachings and akhlakul karimah, can make a real contribution to social life through the implementation of both formal and non-formal education.

\section{Dialectics within Pesantren and Social community}

The dialectic process of pesantren and social community analyzed from Charles Darwin's theory of evolution as explained by Nasrullah Nazsir includes: 1) The struggle for life; 2) those who survive are those who have the best equipment for life (Survival of the fittest); 3) natural selection; 4) progress. Hence, pesantren needs to improve continuously and be adaptive and competent and keep up with every change to survive. ${ }^{17}$

From Darwin's theory point of view, the persistence of pesantren in maintaining the correct values has been one of the aspects which directly related to its existence (Struggle for Life). Every effort done by pesantren is based on the values. It includes establishing educational institutions to maintain and transform the values held and embraced by the pesantren itself (Survival of the fittest). Therefore, the influence of dialectics has an expected impact on Raudatul Ulum Islamic boarding school community and beyond the expectations, as studied by Robert K. Merton's theory on Dysfunction. Furthermore, Robert K. Merton, a naturalistic sociologist, suggests two social functions, the social function of a

${ }^{15}$ Nurcholish Madjid, Merumuskan Kembali Tujuan Pendidikan Pesantren, Dalam M. Dawam Raharjo (Ed), Pergulatan Dunia Pesantren Pesantren: Membangun Dari Bawah (Jakarta: P3M, 1985).

${ }^{16}$ Muammar Ramadhan and Puji Dwi Darmoko, 'Pendidikan Pesantren Dan Nilai Budaya Damai', n.d., https://media.neliti.com/media/publications/195093-ID-pendidikan-pesantrendan-nilai-budaya-da.pdf.

${ }^{17}$ Nasrullah Nazsir, Teori-Teori Sosiologi (Bandung: Widya Padjadjaran, 2008). 
manifest and social latent function. It is in line with Habib Ahmad's study of the impact of manifest and latent toward pesantren's university student in Surabaya. ${ }^{18}$

Meanwhile, Ida Zahara Adibah clearly explained Robert K. Merton's theory that the requirements of Merton's structural analysis cover the recognition of (1) the differentiation process, social structures which can lead to social conflict, (2) the sociological ambivalence develops in normative structures in the form of incompatibilities patterned expectations, and (3) the social structure which causes changes in the structure itself. ${ }^{19}$ Furthermore, according to Kurt Lewin, as stated by Robbin, there are three stages to consider within the social changes: unfreezing, moving, and freezing. ${ }^{20}$

Moreover, amid globalization marked by the movement of borderless changes as well as the era of high-tech high which responsible for various hightechnology tools as an essential part of their lives and brings a significant effect of shifting values in people's lives, ${ }^{21}$ the existence of pesantren, for some people, is considered to be outdated and downright ingenious. ${ }^{22}$ But, on the other hand, pesantren can still attract some people to study for their kids. Therefore, when it is viewed from an anthropological perspective, pesantren can be studied in various aspects. For example, as an educational institution, pesantren can also be considered as a strategic community identity. ${ }^{23}$

The emergence of dialectics with the community is also supported by the condition of Islamic boarding schools, which become the academic, spiritual, moral, and social education institutions. Moreover, Pesantren educates students

${ }^{18}$ Ahmad Habib, 'Fungsi Manifes Dan Fungsi Laten Pesantren Mahasiswa Baitul Hikmah Surabaya', Jurnal Unair 6, no. 1 (2007): 72-82.

${ }^{19}$ Ida Zahara Adibah, 'Struktural Fungsional Robert K. Merton: Aplikasinya dalam Kehidupan Keluarga' 1, no. 1 (2017): 14.

${ }^{20}$ Stephen P. Robbins, Perilaku Organisasi: Konsep, Kontroversi, Aplikasi (Jakarta: Prenhallindo, 2001).

${ }^{21}$ Fauzi, 'Peran Pendidikan Dalam Transformasi Nilai Budaya Lokal Di Era Millenial', INSANIA : Jurnal Pemikiran Alternatif Kependidikan 23, no. 1 (19 December 2018): 51-65, https://doi.org/10.24090/insania.v23i1.2006.this study is also directed at critically analyzing the problems and impacts of the advancement of the information age for humans in the form of the loss of a distinctive identity as a human in his dialectics with his social and cultural system. With the critical phenomenology approach, it is illustrated that this information era leads to the age of uniformity of systems and value of human life with the spirit of a single universal culture. This context poses a serious threat to the loss and scrape of wisdom values over the value of locality. The value of local culture which is the driving force and controlling the crisis of human existence must be carried out transformation efforts towards a new direction in accordance with the spirit of locality and globality (glocalization

${ }^{22}$ DM Herman, 'Sejarah Pesantren Di Indonesia.', Jurnal Al-Ta'dib 6, no. 2 (2013): 14558.

${ }^{23}$ Ridwan Mahfudz, 'Mendorong Pesantren Sebagai Agen Pendamping Perubahan Di Masyarakat' (Digital Library Responsible Development International (RDI), 2005). 
in practical life within social communities in carrying out social roles (Social Role). Therefore, as an educational institution and a community cultural medium, Islamic boarding schools can play an active role in social life.

In this context, pesantren has become one of the educational institutions capable of having a dialectic relationship with a social community with certain values such as tolerance, mutual respect, and adhering to Islamic teachings. Social relations that experience dialectics and transformation make pesantren compatible with social community conditions. It prioritizes inclusive cultural values. This condition eventually gives rise to pesantren as institutions with special and unique characteristics that have excesses and a strong influence on the cultural values of the social community. On the other hand, the last few decades in the social life relations of pesantren as unpretentious institutions have often been stigmatized as the camouflage of life through the struggling of the afterlife problems. Then the pesantren was also reviled as the center of Fatalist's life because of its role in producing the pattern of life that left the material world (Zuhud). It is even more 'harsh' when pesantren has been named the center of radicalism, which shakes the pesantren's position as the 'village of civilization. ${ }^{24}$ This bitter reality requires pesantren to appear elegantly and openly so that a harmonious dialectic occurs with social community and restores the legitimacy of a torn social community.

\section{RESEARCH FINDINGS AND DISCUSSION}

\section{History of the Raudlatul Ulum Islamic Boarding School}

Raudlatul Ulum Islamic Boarding School is an Islamic institution born based on the inclination and needs of the social community. The pesantren and the community founder have formed a harmonious relationship and become an inseparable part of a subculture. From its flexible nature, from the beginning, pesantren has been able to adapt and meet the demands of the social community.

Raudlatul Ulum Islamic Boarding School was founded on July 7th, 1987 by K. Bukhari in Curahtakir Tempurejo Jember. Before the existence of the pesantren, there was only formal education in the form of junior high school. Meanwhile, K. Bukhari still lives in the house of his in-laws, KH Dhofir.

At that time, the condition of the social community was still deficient, especially in terms of religion and education. They are Muslim, but many do not carry out their obligations as Muslims. For example, they do not do salat, fasting, and many others. However, they did not commit immoral acts, such as stealing or robbing. Instead, they live peacefully by farming.

${ }^{24}$ Djohan Efendi, Pesantren Dan Kampung Peradaban, Sebuah Pengantar Dalam: Hasbi Indra, Pesantren Dan Transformasi Sosial: Studi Atas Pemikiran K.H. Abdullah Syafi'ie Dalam Bidang Pendidikan Islam (Jakarta: Pena Madani, n.d.). 
In the beginning, $\mathrm{K}$. Buchori, alongside other community leaders, including Drs. Junaidi, Drs. Abdul Kholiq, H. Badrus Sholeh, and H. Hasan Baidawi, and Ustad Ali Wafa began to provide teaching and recitation of the kitab kuning (an Islamic scholar books), which aims to improve people's faith and morals as well as increase religious knowledge in the community. The teaching and books taught, namely Tawhid, Fiqh, Hadith, and Islamic history, can be seen.

Many of the people then were fond of studying religion at this pesantren. Provided with the knowledge he has and the way he is, which represents the ability to adapt, interact, and teach, he was able to educate and foster people to be faithful, pious, knowledgeable, and noble.

Then, alongside the com m unity, a mosque was built. A bamboo-based building to worship act and teach religious knowledge to the social community starting from children, adults, to the elders with a classical system of different learning levels in each class. It was held in the morning from 05.30 am to $07.30 \mathrm{pm}$. After some time, many people from other villages wanted to become students at this Islamic boarding school. However, most of them came from the city of Jember.

At the beginning of its establishment, the only facilities available were a prayer room and a classroom building, which came from the local community, namely H. Amir, and from the funds issued by the founder himself. Then the Diniyah Madrasah was formed only up to three classes. The curriculum used was the Islamic boarding school curriculum, 100\% related to the religious lessons, with four teachers, including KH. Buchori himself, Ust. Luqman, Ust. Hasan, and Ust. Roqib, the majority of the students came from Curahtakir village, both male and female, and only some came from other areas.

Then, bec a use more and more students wanted to learn, a three-room boarding house for male students of wood was built. A dormitory for girls was also built in a three-room on a one-story building.

The teaching system used is classical recitation and non-classical reading of books with traditional methods; sorogan, wetonan, and bandongan held during the day for Madrasah Ibtidaiyah in the morning and at night for reciting Islamic books or non-classical.

To answer the needs of public education and the changes that occurred and fortify the problems that arose, in morals, values, and culture, in 1999, a one-story building was built as a formal office. The change followed this in which Raudlatul Ulum Middle School is registered as a formal institution with a curriculum adapted to the Ma'arif Middle School curriculum, 30\% religious lessons, and $70 \%$ general subjects.

In line with the increasing number of santri and the community's need for education, the Islamic boarding school finally carried out various developments. 
It starts from physical development. For example, increase the number of rooms and buildings, and develop educational institutions. It includes Raudlatul Atfal (RA) in 1999; Madrasah Aliyah in 2004; non-formal educational institutions, such as the Al-Qur'an Educational Institute (TPQ) in 1999, and a boarding school organization, namely Raudlatul Ulum Santri Association (ISARU) in 2000; foundation which oversees all educational units in the Islamic Boarding School.

As previously explained, pesantren has two great potentials, namely formal and non-formal education. In accordance with this potential, Raudlatul Ulum Islamic Boarding School has also formed an institution given explicitly to the surrounding community, such as majlis ta'lim/istigosah followed by spiritual lectures and preaching at every major Islamic daily activity (PHBI).

\section{Dialectics of Raudlatul Ulum Islamic Boarding School and social community in cultural values transformation through Formal Education}

Based on USPN No. 20 of 2003, formal education includes pre, primary, and higher education. The contribution given and carried out by Raudlatul Ulum Islamic Boarding School through formal activities, such as:

a. Raudlatul Atfal (RA)

Raudlatul Atfal is a pre-school educational institution with a maximum learning period of 3 (three) years before entering elementary school. Raudlatul Atfal Raudlatul Ulum is a preschool educational institution that was founded in 1994. The curriculum used is fitted to the educational goals of the Islamic Boarding School itself and a general curriculum that aims to enable students to develop cognitive, psychomotor, and emotional abilities. So that later, they are ready and can register to Madrasah Ibtidaiyah. ${ }^{25}$

b. Madrasah Ibtidaiyah (MI) Raudlatul Ulum

Madrasah Ibtidaiyah Raudlatul Ulum is the first educational institution established in 1997. The curriculum used is the Indonesian Ministry of Religion curriculum, having 30\% religious lessons and 70\% general subjects. The majority of Madrasah Ibtidaiyah come from the surrounding social community within the Islamic Boarding Schools. A few of them are santri of the pesantren itself. It seems that the people around the pesantren prefer to register their children in this Raudlatul Ulum Madrasah Ibtidaiyah. As Mr. Subandi says that he chose Madrasah Ibtidaiyah because he wanted his sons and daughters to have a balanced scientific provision between general knowledge and religious knowledge.

${ }^{25}$ Interview with the principal of RA. Nyai. H. Muzayanah Tgl. 16 Nopember 2020 
c. Madrasah Tsanawiyah (MTs) Raudlatul Ulum

Madrasah Tsanawiyah is an education level with the same level as SMP providing education with 3 (three) years of the learning program. MTs. Raudlatul was founded in 1999 using the MoRA curriculum. RI., which covers 30\% religious knowledge and 70\% general knowledge. Meanwhile, SMP Ma'arif Raudlatul Ulum was founded in 1997 using the Dinas and Ma'arif curriculum. Initially, MTs Raudlatul Ulum was a branch of MTs Nurul Hikamah which eventually moved to Curahtakir Village because of Raudlatul Ulum Curahtakir Tempurejo Principal focusing his education on Islamic boarding school lessons. Meanwhile, Ma'arif Middle School has initially been named SPG C2, which KH founded. Dhofir Ar Syah and his son-in-law $\mathrm{KH}$. Abdullah Yaqien. Originally this SMP was in the PP Nurul Hikamah setting raised by KH.ABD. Wafir W, but eventually they were combined with MTs Raudlatul Ulum located at Jl. Suprijadi No.16 Curahtakir. Some of these students who study at MTs and SMP live in Islamic boarding schools, especially female students whose homes are far from the Islamic boarding schools. Thus, fostering students to deepen their religion to be applied in social life can be implemented ${ }^{26}$.

d. Madrasah Aliyah Raudlatul Ulum

Madrasah Aliyah Raudlatul Ulum, founded in 2009, is a high school level secondary education institution that meets the needs of the community and students. According to the Principal of Madrasah, M. Maulana Y.S.Pd.I., the establishment of this MA was to meet the needs and demands of the community and their parents who want to improve the education of their sons and daughters to a higher level without having to find or move elsewhere. In addition, the aim is to improve the quality of Islamic boarding school education, general education, and religious education. The current phenomenon revealed that people no longer regard Islamic boarding schools as only places to seek religious knowledge and other general knowledge. The observable fact showed that students at the Miftahul Ulum Islamic Boarding School tend to move to another school after they graduated from a certain level of education, to continue their study to a higher level of education because, at that time, the Miftahul Ulum Islamic Boarding School education only reached MTs.

So the students are only at the MTs level or maybe around the maximum age of 17 . Therefore, it impacts the quality of religious education, especially the Islamic book taught and the grade of its alumni. Ustadz Ali Wafa and Kamil strengthen the statement by saying that the purpose of establishing MA was

${ }^{26}$ Interview with Gus Sodik 
to develop and improve the educational level of its social community. It was because they had not paid much attention to the education of their children. They only send their children to the MTs school level. After that, if they did not get married, they helped their parents. ${ }^{27}$

The curriculum used is the MA curriculum, with $30 \%$ religious knowledge and $70 \%$ general knowledge. Because it was only a year old institution, the number of students was still very minimum. There are 32 students in total. Some of them come from Islamic boarding school students and others from outside the boarding school students who only go to school and do the AlQuran recitation without staying in the boarding school. The obstacle faced in realizing MA Raudlatul Ulum comes from the awareness of the community of the children's education and less motivation. Apart from that, the internal factors of the institution itself, it seems that there is still a lack of preparation. Many things need to be addressed, such as administrative problems and a lack of teaching staff. ${ }^{28}$

Based on these data, it can be said that the contribution of Raudlatul Ulum Islamic Boarding School in the educational context is massive. Islamic boarding schools with all existing potential, such as education and community development, have made a real contribution to education (Manifest function). As an Islamic education institution and social institution, Islamic boarding schools always emphasize the transformation of Islamic religious values in every program implemented. In contrast, according to Henry Noer Aly and Manzier, they emphasize that there are two values which are 'to value' and 'to evaluate. ${ }^{29}$ These values emphasize the balance between religious knowledge and general knowledge. It is applied in the form of educational institutions, both formal education and non-formal education. In this case, considering the importance of an Islamic boarding school, this research result strengthens Kamaruzzaman Bustamam-Ahmad. He said that there would be no uniqueness of the Islamic tradition if there were no pesantren or madrasas. ${ }^{30}$

In accordance with Law No. 20 of 2003 concerning the National Education System, education in Indonesia is implemented through two channels; formal and non-formal channels. The levels of school education ranging from primary education, secondary education and higher education. ${ }^{31}$

${ }^{27}$ Interview with Gus Sodik

${ }^{28}$ Interview with Nuryanto

${ }^{29}$ Hery Noer Aly and Munzier, Watak Pendidikan Islam (Jakarta: Friska Agung Insani, 2003).

${ }^{30}$ Kamaruzzaman Bustamam Ahmad, 'Educational Practice: Lessons to Be Learned from Madrasah and Religious Schools in Contemporary Southeast Asia', Indonesian Journal of Islam and Muslim Societies 5, no. 1 (1 June 2015): 29, https://doi.org/10.18326/ijims.v5i1.29-48.

31 'Undang-Undang No 20 Tahun 2003 Tentang Sistem Pendidikan Nasional', n.d. 
Raudlatul Ulum Islamic Boarding School, since its establishment, has paid more attention to educational issues. It can be seen from the existence of Raudlatul Athfal (RA), Madrasah Ibtidaiyah (MI), Madrasah Tsanawiyah (MTs), and Madrasah Aliyah (MA). They are characterized by a combination and balance between general knowledge and religious knowledge, which aims to form human beings who are faithful, devoted, knowledgeable, and have good character.

\section{Dialectics of Raudlatul Ulum Islamic Boarding School and social community in cultural values transformation through Non-formal Education}

Raudlatul Ulum Islamic Boarding School does not focus more on formal and non-formal education within the educational context. Both are equally important and must be developed to form faithful, religious, knowledgeable, and good character. However, it is in the Diniyah Education and other pesantren activities that has become one of the distinctive activities done by santri to study religion more deeply.

For more details regarding the contribution of Islamic boarding schools to non-formal education, the following are the description of programs in the pesantren:

a. Madrasah Diniyah

Madrasah Diniyah is a madrasah that only teaches religious knowledge. This institution is divided into three levels, namely: Ula, Wustha, and 'Ulya. Madrasah Diniyah Raudlatul Ulum is an educational institution where all of the pesantren's students (santri) must participate. The Principal of Madrasah Diniyah Raudlatul Ulum, Lutfi Zyahrandi, Madrasah Diniyah is the core and most essential program for all students. This program aims to produce santri with strong religious provisions and produce ulama (Islamic scholars) cadres who are beneficial to social communities.

The curriculum used is a $100 \%$ pesantren-based curriculum implemented in the morning and afternoon. It is because it lacks teaching staff and the crashed scheduled towards the formal education. In this Madrasah Diniyah, a recitation program should differ between the two in its implementation. But because of the lack of teaching staff, the recitation program is only done at night.

In 2020, due to the relatively very young age of santri and the ability to understand the Islamic books is very low, the consequence was that it affects the types and levels of books that must be adjusted to the skills of the santri himself. According to K. Sodik as the Principal at Madrasah Diniyah, he would not give lessons or recitation of Islamic books whose quality was not in accordance with the students' abilities because it would be useless. According 
to him, it was less effective. Madrasah Diniyah is an institution that effectively instills and transforms religious values and media to produce santri and social community who are religious, knowledgeable, and have good character. ${ }^{32}$

b. Al-Qur'an Recitation

The Al-Qur'an recitation for the Raudlatul Ulum Islamic Boarding School is a very vital program. It is also mandatory for all of the santri, both male and female, junior and senior. This program aims to create a Qur'an santri who can recite Al-Quran correctly and adequately in tajwid, mahroj, and intonation. Moreover, it is expected to be understood, lived, and applied in everyday life and value for the community. ${ }^{33}$

The education system applied is the Khalaqoh / group system. The students are grouped according to their respective abilities in different materials. Group I is a group of students who have just joined the program, and their reading ability is still at the basic level. The material that is emphasized is the improvement of makharijul letters and fluency in reading. Group II is a continuation of group I, where the underlined material is recitation and reading fluency. Group III, as the last stage having some of the learning material and mastery of difficulties in readings known as Gharib. Above group III, a selection or examination of reciting Al-Quran was held. They were given the task of guiding students from groups I and II. ${ }^{34}$

The teaching method implemented within groups I to III is the same. Students read a verse accompanied by a beat by the guidance. After that, the question was asked about the names of the recitation of Al-Quran or their tajwid one by one and then read them all together.

c. Majlis Ta'lim

What is meant by majlis ta'lim, in this case, does Raudlatul Ulum Islamic Boarding School group carry out religious activities in the form of recitation for the social community around the Islamic Boarding School in particular and social community in general. This activity is carried out on Jum'at manis (one of Fridays based on Javanese weton) led by the Principal. At first, this activity varied, some specifically for males, females, but in 2017, only the recitation carried out specifically for males survived. Every Friday afternoon, they come to K. Bukhari, which is now done by his son Gus Sodik, to gain spiritual insight and religious knowledge. The material presented is not monotonous; every Friday, the material changes. The material revolves around the issue of faith, the act of worshiping Allah, and social lifestyle. Within its implementation, it is preceded by reciting the istigosah and the interpretation of the Al-Quran.

\footnotetext{
${ }^{32}$ Interview with Gus Sodik November 17th 2020

${ }^{33}$ Interview with staffs: M.Hijrah Akbar syah, on November 17th 2017

${ }^{34}$ Interview with staffs of educational sections, Abd.Muttalih on November 13th 2017
} 
Then he started lecturing, sometimes taking information and carrying a kitab kuning and sometimes other knowledge. The benefits generated from this activity are enormous and give tangible results. The observable fact that can be seen from the discussions that occurred so far; they are already fluent and even memorized the istigosah and yasin recitation and developments in their religious quality. ${ }^{35}$

Based on these activities, Islamic boarding schools, known as educational institutions with religious characteristics, were considered a place to study and deepen the aspect of religion or what is called Tafaqahû Fi Al-Dìn. Pesantren has a very significant influence on the culture of the surrounding community by focusing on the role of the kyai in educational and cultural activities that are pesantren in nature. ${ }^{36}$ The community considers that pesantren is a place to form a whole person who has a strong religious attitude and provision to face changes. According to Anika Ni'matun Nisa and Suharno, only prosperity changes; it can be achieved even to face the future. ${ }^{37}$ Because within Islamic Boarding School habituation and practice methods are applied, santri are given theories or provisions about religion, acts of worship, how to behave, socializing with others, and so forth. Then, they use it in the form of prayers five times a day and learn to recite Al-Quran. It is under the supervision of the Principals or the supervisor board to be applied and accustomed to social life within pesantren's environment and the wider community. Such habits then become the milestone and the indicator of santri's cultural knowledge, where the typology of the relationship between Islam and culture, Javanese culture, in particular, is not contradictory but dialectical..$^{38}$ Muhammad Ali's statement reinforces that the relationship between Islam and the social community is reflected in a view that it emphasizes practical Islam where Islamic customs and law are considered a system rather than two different entities. ${ }^{39}$

\section{CONCLUSIONS}

Based on the data analysis and discussion, presented the following conclusion. First, the dialectics of pesantren and social community in transforming cultural values through formal education was done by establishing several

${ }^{35}$ Interview with KH.Baidhowi on November 17th 2017

${ }^{36}$ Fahruddin, 'The Existence of Pesantren in The Dutch East Indies Government Pressure', Cendekia: Jurnal Kependidikan Dan Kemasyarakatan 18, no. 2 (2020): 351-61.

${ }^{37}$ Anika Ni'matun Nisa, 'Perubahan Masyarakat Melalui Program Rumah Harapan Karangpatihan Bangkit Untuk Mengatasi Kemiskinan’ 18, no. 2 (2020): 24.

${ }^{38}$ Sulistiyono Susilo and Ibnu Syato, 'Common Identity Framework of Cultural Knowledge and Practices of Javanese Islam', Indonesian Journal of Islam and Muslim Societies 6, no. 2 (14 December 2016): 161, https://doi.org/10.18326/ijims.v6i2.161-184.

${ }^{39}$ Syamhari, 'Transformasi Nilai-Nilai Budaya Islam Di Sulawesi Selatan'. 
84 Subakri dkk, Dialectics of Pesantren

formal educations. Second, the dialectics of pesantren and social community in transforming cultural values through non-formal education was done by establishing several non-formal religious-based institutions through pesantren activities. 


\section{REFERENCES}

Adibah, Ida Zahara. 'Struktural Fungsional Robert K. MERTON: Aplikasinya dalam Kehidupan Keluarga’ 1, no. 1 (2017): 14.

Ahmad, Kamaruzzaman Bustamam. 'Educational Practice: Lessons to Be Learned from Madrasah and Religious Schools in Contemporary Southeast Asia'. Indonesian Journal of Islam and Muslim Societies 5, no. 1 (1 June 2015): 29. https://doi.org/10.18326/ijims.v5i1.29-48.

Aly, Hery Noer, and Munzier,. Watak Pendidikan Islam. Jakarta: Friska Agung Insani, 2003.

Azra, Azyumardi. Esei-Esei Intelektual Muslim Dan Pendidikan Islam. Cet. 1. Ciputat: Logos Wacana Ilmu, 1999.

Dakir and Umiarso Umiarso. 'Pesantren dan Perubahan Sosial: Optimalisasi Modal Sosial Bagi Kemajuan Masyarakat'. Al-A'raf : Jurnal Pemikiran Islam Dan Filsafat 14, no. 1 (27 June 2017): 1. https://doi.org/10.22515/ajpif. v14i1.587.

Efendi, Djohan. Pesantren Dan Kampung Peradaban, Sebuah Pengantar Dalam: Hasbi Indra, Pesantren Dan Transformasi Sosial: Studi Atas Pemikiran K.H. Abdullah Syafi'ie Dalam Bidang Pendidikan Islam. Jakarta: Pena Madani, n.d.

Fahruddin. 'The Existence of Pesantren in The Dutch East Indies Government Pressure'. Cendekia: Jurnal Kependidikan Dan Kemasyarakatan 18, no. 2 (2020): 351-61.

Fauzi. 'Peran Pendidikan Dalam Transformasi Nilai Budaya Lokal Di Era Millenial'. INSANIA : Jurnal Pemikiran Alternatif Kependidikan 23, no. 1 (19 December 2018): 51-65. https://doi.org/10.24090/insania.v23i1.2006.

Habib, Ahmad. 'Fungsi Manifes Dan Fungsi Laten Pesantren Mahasiswa Baitul Hikmah Surabaya'. Jurnal Unair 6, no. 1 (2007): 72-82.

Herman, DM. 'Sejarah Pesantren Di Indonesia.' Jurnal Al-Ta'dib 6, no. 2 (2013): 145-58. 
Kariyanto, Hendi. 'Peran Pondok Pesantren Dalam Masyarakat Modern', n.d. https://ejournal.iainbengkulu.ac.id/index.php/multikultura/article/ view/2495.

Lombard, Zamakhsyari Dhofier. Tradisi Pesantren, Studi Tentang Pandangan Hidup Kyai. Archipel., 1984.

Madjid, Nurcholish. Merumuskan Kembali Tujuan Pendidikan Pesantren, Dalam M. Dawam Raharjo (Ed), Pergulatan Dunia Pesantren Pesantren: Membangun Dari Bawah. Jakarta: P3M, 1985.

Mahfudz, Ridwan. 'Mendorong Pesantren Sebagai Agen Pendamping Perubahan Di Masyarakat'. Digital Library Responsible Development International (RDI), 2005.

Muniruddin. 'Komunikasi Pengembangan Masyarakat Islam Analisis Teori Dialektika Relasional'. Jurnal Pemberdayaan Masyarakat 7, no. 1 (24 August 2019): 13. https://doi.org/10.37064/jpm.v7i1.5608.

Mustari, Mohammad, and Dedeng Yusuf Maolani. 'Manajemen Pesantren Dalam Pembangunan Desa'. TEMALI : Jurnal Pembangunan Sosial 1, no. 2 (1 October 2018): 167-92. https://doi.org/10.15575/jt.v1i2.3214.

Nazsir, Nasrullah. Teori-Teori Sosiologi. Bandung: Widya Padjadjaran, 2008.

Nisa, Anika Ni'matun. 'Perubahan Masyarakat Melalui Program Rumah Harapan Karangpatihan Bangkit Untuk Mengatasi Kemiskinan’ 18, no. 2 (2020): 24.

Observasi dilakukan pada tanggal 1 Nopember 2020, n.d.

Ramadhan, Muammar, and Puji Dwi Darmoko. 'Pendidikan Pesantren Dan Nilai Budaya Damai', n.d.https://media.neliti.com/media/publications/195093. ID-pendidikan-pesantren-dan-nilai-budaya-da.pdf.

Ratnawati, Siti Rohmaturrosyidah. "Multiculural-Based Islamic Religious Education in Ahmadiyah's School: A Strategy to Strenghten the Moderation Vision of Indonesian Islamic School." Cendekia: Jurnal Kependidikan dan Kemasyarakatan, 18, no. 1 (13 April 2021); 2020: 117-137. https: doi. org/10.21154/cendekia.v1i1.1787

Robbins, Stephen P. Perilaku Organisasi: Konsep, Kontroversi, Aplikasi. Jakarta: Prenhallindo, 2001. 
Royani, Ahmad. 'Eksistensi Pendidikan Pesantren Dalam Arus Perubahan'. Cendekia: Jurnal Kependidikan Dan Kemasyarakatan 16, no. 2 (22 November 2018): 375. https://doi.org/10.21154/cendekia.v16i2.1242.

Shodiq, M. 'Pesantren dan Perubahan Sosial', Jurnal Sosiologi 1 (2011): 12.

Sudin, Mahmuddin. 'Pesantren, Transformasi Sosial Dan Kebangkitan Intelektualisme Islam', n.d. https://jurnal.umj.ac.id/index.php/MaA16/ article/view/3816.

Susetyo, Bagus. 'Identifikasi Dekulturasi Sebagai Teori Perubahan Kebudayaan Dalam Musik Indonesia : Kajian Proses Perubahan Rebana Menjadi Kasidah Modern Di Kota Semarang'. Jurna Humaniora Unnes, 2010, 11.

Susilo, Sulistiyono, and Ibnu Syato. 'Common Identity Framework of Cultural Knowledge and Practices of Javanese Islam'. Indonesian Journal of Islam and Muslim Societies 6, no. 2 (14 December 2016): 161. https://doi. org/10.18326/ijims.v6i2.161-184.

Syamhari. 'Transformasi Nilai-Nilai Budaya Islam Di Sulawesi Selatan'. Rihlah : Jurnal Sejarah Dan Kebudayaan 2, no. 2 (2015).

'Undang-Undang No 20 Tahun 2003 Tentang Sistem Pendidikan Nasional', n.d.

Yunus, Rasid. 'Transformasi Nilai-Nilai Budaya Lokal Sebagai Upaya Pembangunan'. Jurnal Penelitian Pendidikan (JPP), Universitas Pendidikan Indonesia 13, no. 1 (2013). 